\title{
Laryngeal Cancer TNM Finding v7
}

National Cancer Institute

\section{Source}

National Cancer Institute. Laryngeal Cancer TNM Finding v7. NCI Thesaurus. Code C89048.

A finding about one or more characteristics of laryngeal cancer, following the rules of the TNM AJCC v7 classification system. Nonepithelial tumors such as those of lymphoid tissue, soft tissue, bone, and cartilage are not included in this classification. (from AJCC 7th Ed.) 